Gabriella SCHUBERT*

Friedrich-Schiller-Universität

Jena
Оригинални научни рад

Примљен: 23. 10. 2020.

Прихваћен: 25. 2. 2021.

\title{
ПРИПОВЕДАЮЕ О ЧАКУ НОРИСУ НА ИНТЕРНЕТУ У ЈУГОИСТОЧНОЈ ЕВРОПИ, ПОСЕБНО У СРБИЈИ
}

\begin{abstract}
Приповедање на интернету о америчком борилачком спортисти и акционом глумцу Чаку Норису је широко распрострањено у свим земљама Југоисточне Европе, стога и у Србији. Изјаве о Норису које тематизују његову натприродну физичку снагу иронично се зову „чињеницама”, јер су супротне стварности и вероватноћи. У њима је Чак Норис увек победоносни херој. Његов ауторитет и његове способности превазилазе физичку снагу: он побеђује више силе, пандемију па чак и смрт; корона вирус се плаши њега а не обрнуто. У „чињеницама” о Чаку Норису у Југоисточној Европи међународни наративи највише служе као узор, али његова личност често је повезана са специфичним историјским и актуелним политичким и друштвеним темама сопствене земље и миљеа.

Кључне речи: Чак Норис, нарација на интернету данас, друштвене мреже, интернет портали, амерички акциони филмови, извештаји и „чињенице” о Чаку Норису.
\end{abstract}

\section{I . Стварање фолклора данас}

Све до наших времена, усмени фолклор је био у центру пажње балканолошко-фолклористичких истраживања, посебно у региону Југоисточне Европе, и то још и у првој половини XX века, када је усменост у стварању, репродукцији и традицији песама, бајки, легенда, митова и других наративних жанрова већ углавном припадала прошлости, изузев неких села, како у Србији тако и у другим деловима Југоисточне Европе. ${ }^{1}$

Текстови усменог стварања које су прикупили Вук Стефановић Караџић и други махом су се појавили у XIX и XX веку. Наравно, ове публикације нису замена за аутентично фолклорно стварање ранијих столећа. Све већи број објављених зборника фолклорних текстова допринео је чињеници да су

\footnotetext{
*gabriella.schubert@gmx.de

${ }^{1}$ Ludwig 2008: 363-364 у овом контексту пише о усменом фолклорном стварању старије генерације у северној Албанији.
} 
ти зборници временом чак и изгубили свој претходни статус драгоценог производа. У све већој мери, обележили су транзицију од фолклора у популарну књижевност (в. на пример Динеков 1976, I: 3-12).

Нарација је, међутим, и данас остала важан део друштвеног живота, важан фактор комуникације у свакодневном животу као и у свим приликама и на местима где се људи састају и тиме се пружа могућност за нарацију: у пабовима и ресторанима, у клубовима, на фудбалским стадионима, у поворкама или политичким и другим састанцима. Тако, на пример, Чоловић (1994) пише о фолклорним порукама политичара у бившој Југославији којима су желели да манипулишу народом током демонстрација против Милошевића (уп. Čolović 1994: 20 и Schubert 1998). ${ }^{2}$

У целини узето, жанрови фолклора и њихово преношење с временом су постали разноврснији: поред штампаних књига, данас су и новине, радио, филм и телевизија постали носиоцима фолклорног стварања (в. између осталог Schubert 2014: 543-544). ${ }^{3}$ Linda Dégh (1994) у вези са тим примеђује: „[T]echnical reproductivity dictated a different pace for folklore communication through new media..." (Dégh 1994: 1).

Поред тога, фолклорне поруке садрже и изборни постери, слике на зидовима и на тротоару (в. Schubert 2011. и 2014: 576-579).

На првом месту нових медија који шире фолклор, налази се интернет (в. Schneider 1996: 26), посебно с обзиром на то да је интернет део свакодневног живота широм света, а самим тим и у Југоисточној Европи. Интернет више није ограничен на младу генерацију; у Србији као и у Хрватској, око 75 одсто становника данас користи интернет ${ }^{4}$ - за информисање, комуникацију, забавне активности и нарацију.

\section{II. Приповедање на интернету}

Многобројне блоговске заједнице у Југоисточној Европи корисницима платформу за приповедање из сопственог живота или коментарисање специфичних тема и извештаја из свакодневног приватног или свакодневног живота. Помоћу друштвених мрежа као што су Фејсбук, Твитер или Инстаграм, које користе сви слојеви становнштва у земљама Југоисточне Европе, тако и у Србији, постоји могућност да људи међусобно контактирају, мењају утиске, доживљаје и мишљења. Неки портали нуде готово синхрону размену у приповедању као што је на пример Bolchat.org.

\footnotetext{
${ }^{2} \mathrm{O}$ сличним појавама односно оживљавању импровизованих песама о миграцији радне снаге (këngë kurbeti) и политичким догађајима у сатиричном облику у Албанији пише Pistrick 2008.

${ }^{3}$ Čistov (1977: 78) у овом контексту пише о „квази-усменим” облицима садашњости.

4 https://www.jutarnji.hr/life/tehnologija/znate-li-u-kojoj-drzavi-najvise-koriste-internet-na-samom-dnu-je-diktatura-kim-jong-una-a-hrvatske-brojke-iznenaduju.../93829/; https://ivanacirkovic. com/drustveni-mediji/kako-ljudi-u-srbiji-koriste-internet/ Примедба: Овај сајт и следећи сајтови су коришћени 2. јуна 2020. г.

${ }^{5}$ Као на пример http://www.blogoslavija.com/, HTTP://PLANETOID.SRPSKI.ORG/, BLOG.BG.
} 
Корисници шаљу порталима извештаје о личним доживљајима и другим, чак и интимним темама, обично у стилу свакодневног језика (напр. Roth 2009. и Fialkova, Yelenskaya 2001: 75-79). Анонимност, отвореност и висок степен флексибилности као предуслови нарације на интернету, одају утисак да је реч о фолклорној комуникацији, иако се овде ради о једносмерном креативном процесу, о индиректној комуникацији и асинхроној нарацији. Пошиљалац, односно наратор, и прималац су, наиме, одвојени један од другога, а наратор тек мало касније или после одређеног времена добије одговор. У фолклорној комуникацији преко интернета по традиционалном схватању недостају неопходни предуслови стварања: усменост, нарација face to face и наративна заједница. Исто тако, на интернету не може да се прати процес дифузије фолклорног стварања. Ипак, приповедање на интернету је данас један од најпопуларнијих начина комуницирања. На пример, портал Balkanesia поздравља своје кориснике на следећи начин:

Добро дошли на Балкански форум. Ви сте први пут овде? У том случају постаните бесплатно члан наше заједнице и учествујте у узбудљивим разговорима око теме балканских земаља и добићете брзе и корисне одговоре на своја питања. Градимо мостове између прошлости и будућности.

На сличан начин, сајт В92 Блог под насловом Забава. Вищеви, шале и поучне приче $e^{7}$ позива кориснике да се укључе у дигитални дијалог на следећи начин: „Молимо Вас да се улогујете или региструјете да бисте могли да шаљете коментаре.”

Са повећаним бројем медија, прилика и могућности за нарацију, њени обрасци и садржаји су се мењали: виц, модерна сага и разне приче о актуелним догађајима свих врста, о политичарима и корупцији, проминентним људима и приватним искуствима заузели су место традиционалних наративних жанрова и садржаја. У неким случајевима су чак и преузели узоре приповедања прошлих времена, али су се прилагодили модерним контекстима и тематски су често мотивисани актуелним медијским извештајима. У том контексту, Рот (2008) на пример пише о актуелној потреби многих корисника у Бугарској да приповедају о својим проблемима у социјалистичком времену на једном, за ту тему, новоствореном порталу. ${ }^{8}$ И у Србији постоји сличан, југоносталгичан интернет портал. ${ }^{9}$

Најпопуларнији интернет портали у Југоисточној Европи, као и широм света, јесу виц портали као што су www.vicevi.rs, www.vicevi.net, www. vicmaher.com, www.bancuri.net, mioritice.libertatea.ro и други. Вицеви које корисници шаљу тим порталима - најчешће анонимно и делимично под именом и са датумом - груписани су по главним ликовима и темама. Неки од њих, на пример на српском интернет сајту www.vicevi.rs, припадају истим ликовима и темама које су познате из штампаних збирки вицева као што су

\footnotetext{
${ }^{6} \mathrm{http}: / /$ balkanesia.com/forum.php.

${ }^{7} \mathrm{http}: / /$ blog.b92.net/text/20327/VICEVISALE-I-POUCNE-PRI.

${ }^{8} \mathrm{http}$ ://www.mediapool.bg/parvi-sait-za-lichni-istorii-ot-sotsializma-wwwspomeniteniorg-news10281.html.

${ }^{9}$ www.kurir-info.rs.
} 
Мујо и Хасо, Перица, Пироћанции, Земунции, Црногоричи и Цигани. Многи други су посвећени темама данашњег живота, између осталог политичарима, полицајцима, компјутерима или међународним популарним темама као што су плавуше, полицајци или животиње.

\section{III. Чак Норис}

Вицеви о Чаку Норису, америчком борилачком спортисти и акционом глумцу, који је прославио свој осамдесети рођендан 10. марта 2020. године, познати су и омиљени у читавом свету па и у Југоисточној Европи.

Чак Норис (правилно Carlos Ray Norris Jr.) је најстарији син родитеља, који су пола Чироки, пола ирског порекла. Рођен је у Оклахоми. После завршетка средње школе, 1958. године, придружио се Ваздухопловним оружаним снагама (United States Air Force) Сједињених Држава. У Тексасу је стекао војно образовање код Ваздухопловних оружаних снага. Године 1960. су га послали као члана војне полиције у Кореју. Тамо је стекао своју умешност у корејским борилачким техникама Tang Soo Do и Taekwondo. Био је први човек са Запада који је освојио највиши ранг (8. Dan) у Taekwondo-y. Свој надимак Chuck је добио од својих другова. Године 1962. године је основао сопствену борилачку школу, која се проширила у читав ланац. Као војник, на почетку је био стациониран у Калифорнији; а на крају своје четворогодишње службе је напустио Ваздухопловне оружане снаге.

Због недостатка новца Чак Норис почиње да се бави бизнисом. Бивши војни полицајац добија улоге као каскадер у акционим филмовима и стиче популарност у филмовима као што је Way of the Dragon (1972), Black Tiger (1978), A force of one (1979), Missing in Action (1984) Missing in Action 2 (1985), Top Dog (1995), у којима је изградио себи имиџ модерног каубоја са надљудским способностима. Највећу популарност је стекао у телевизијској серији Walker, Texas Ranger, која је емитована од 1993. до 2001. у наставцима и као телевизијски филм. Као главни јунак у тој серији, он је у више од 200 епизода између осталог стопирао тестеру у покрету, задавао Roundhousekick-ове и држао кичасте говоре. Ту се вероватно налази полазна тачка данашњих вицева о Чаку Норису.

После 2004. године више није виђен у биоскопима; 2012. године, међутим, вратио се са филмом Expendables 2. У 2010. постао је почасни члан елитне јединице Texas Rangers и добио је званично одликовање са звездом Texas Rangers-a (у вези са Чаком Норисом, в. изм. ост. Sippert 2000).

Његова претерана мушкост и чврстина су подстакнули америчког модератора талк шоуа Late-Night-Show (1993-2009) да направи један виц који се потом раширио широм света. Од тада се свуда шири пародија непобедивог хероја Чака Нориса, борбеног човека који у исто време строго поштује владајуће законе. Његова хипермушка улога је постала популаран шаблон за кратке вицеве и такозване Chuck Norris Facts (чињенице о Чаку Норису), које 
исмејавају његову физичку снагу и његову супериорност. Од 2005. године Chuck Norris Facts круже као интернет-мимови, који се хумористички односе на његове ратничке филмске улоге и борбене вештине. Његове мимове обично прати његова слика у карираној кошуљи са препознатљивом брадом из серије Walker, Texas Ranger. Лично је неколико пута реаговао на интернет-мимове о себи: навео је да има духовитих мимова, али да их не треба схватити озбиљно. Додао је да се нада да ће људима служити као подстрек да гледају на то шта он стварно ради и пише.

Глобално ширење његове популарности показује захтев навијача у Словачкој 2012. да њихов мост Cyklomost slobody добије име Чака Нориса, што се није десило; неколико година раније, навијачи у Мађарској су исто тако тражили да се мост Megyeri именује по њему. ${ }^{10}$

\section{IV. Вицеви и „чињенице” о Чаку Норису}

Чак Норис ствара „чињенице” - тачније невероватне чињенице. У вези са тим у Немачкој је позната следећа такозвана чињеница: Чак Норис не једе мед. Он жваће пчеле. Слична је изрека која је актуелно објављена на једном српском интернет порталлу: Чак Норис не мора да се изолује од короне, корона се изоловала од юега. ${ }^{11}$

То нису тврдње које се заснивају на „чињеницама”, очигледно је да се нису догодиле и не могу да се догоде. Да ли су то вицеви? Традиционално, виц је заснован на принципу смешне супротности. У њему се сударају противречне норме и сфере живота; у другим случајевима реално постојећи појмови и/или речи су постављени у један контекст коме не припадају. Ово је често већ мотивисано двосмисленошћу речи, реченица, термина и слика (види Lixfeld 1984; Bausinger 1980, 138, 138 и сл.). Према Раскиновој теорији о вицевима (Raskin 1985), виц представља бинарну опозицију скриптова који се преклапају изненађујуће; уп.: „,The two scripts with which the text is compatible are opposite [...]. The two scripts with which the text is compatible are said to overlap fully or in part on this text." (Raskin 1985: 99).

Ова структура опозиције је релевантна за извештаје о Чаку Норису. У наведеном немачком примеру Чак Норис не једе мед. Он жваће пчеле делимично се преклапају 'мед' са 'пчелама' и 'не једе' са 'жваће', а опозиција скриптова састоји се у томе да Чак Норис не једе мед, али жваће пчеле. У другим примерима као што је: Чак Норис се не плаши петка 13, него се петак 13. плаши Чака Нориса долази до преокрета односа између 'Чак Норис' и 'петак 13.', реално могуће релације у првом делу у реално незамисливу релацију у другом делу изјаве. Та констелација изазива изненађење, чуђење и осмех, можда и смех. У том смислу, изјаве о Чаку Норису прате узор вица.

\footnotetext{
${ }^{10}$ Chuck Norris leads the way in Budapest bridge-naming vote. Y: The Sydney Morning Herald, 2. August 2006.

${ }^{11}$ https://www.pcnen.com/portal/2020/03/12/samo-cak-noris-moze-da-zaustavi-koronu/
} 
Вицеви, поред опозиције скриптова, традиционално укључују и друге елементе. Уживање слушалаца једног вица у великој мери је засновано на препознатљивости приказаних типова. Оно што је још важније за ову врсту текста, то је поента, боље речено сужавање вица до поенте. Обично се користи стратегија успоравања како би поента испала максимално изненађујућа. Шаљивац не сме да пропусти поенту ако жели да постигне свој циљ, а то је смех слушаоца (в. Schubert 1999). Поента готово увек значи нагли крај вица. Крај обично не пружа решење гротескног или апсурдног контраста у вицу, већ га оставља асоцијативној способности слушалаца. Такве примере исто тако налазимо - иако peђе - међу вицевима о Чаку Норису на интернету. Примера ради наводимо следећи виц у коме се пародира респект смрти према Чаку Норису:

Дошла Смрт са маском, косом, и иде од врата до врата. Дође на једна врата, звони, кад оно, врата отвара Чак Норис. Гледа Смрт Чака Нориса, гледа он Смрт, кад одједном, Смрт дигне руке и викне: МАСКЕНБАЛ!!! ${ }^{2}$

У овом и сличним примерима поента на крају изненада мотивише слушаоца да своју пажњу од првог скрипта пребацује на други, супротни скрипт.

Велики број изјава о Чаку Норису, према томе, има другачију структуру, на пример следећу: „Само Чак Норис може да заустави Корону (пандемију)!!’"13

Структура бинарне опозиција скрипата у овим случајевима није применљива. Ради се о једносмерној изјави, тврдњи истине, која се иронично зове „чињеницом”, јер није вероватна. У њој, Чак Норис се појављује као херој са изузетним способностима. Текстови ове врсте чине већину текстова на интернету. Они у ствари нису смешни, већ представљају персифлажу имиџа једне звезде акционог филма.

Укратко, приче и изјаве о Чаку Норису на интернету осцилирају између дужих и краћих вицева и изјава, и тиме више изазивају осмех, него смех.

\section{V. Типични вицеви и изјаве о Чаку Норису}

V . 1. У свим земљама Југоисточне Европе вицеви о Чаку Норису сачињавају једну важну групу, у којој се тематизује натприродна физичка снага Чака Нориса. Неки од њих преузимају међународне узоре; уп. следеће српске примере:

„Чак Норис је једном убио 2 камена једном птицом.”"14 „Кад су се деца играла у песку, Чак се играо у бетону.”15

\footnotetext{
${ }^{12}$ https://www.vicevi.rs/vicevi/cak-noris.

${ }^{13} \mathrm{https}: / /$ www.bbc.com/serbian/lat/srbija-51834764

${ }^{14} \mathrm{https}$ ://sites.google.com/site/pspkocic/hajde-da-se-smejemo

${ }^{15} \mathrm{https} / / /$ sites.google.com/site/pspkocic/hajde-da-se-smejemo.
} 
У другим изјавама Чак Норис повезује се са темама сопствене земље у Југоисточној Европи; уп. на пример:

„Чак Норис може једини да победи Ђоковића.”' или

„Чак Норис је верник. Он верује у Новака Ђоковића.”"

„Само Чак Норис може да навија за Звезду и Пратизан истовремено.”18

\section{Или пример из Босне:}

„Čak Noris je jedini skočio iz Neretve na Stari most u Mostaru."

V. 2. Ауторитет и способности Чака Нориса, међутим, далеко превазилазе физичку снагу. Чак Норис побеђује више силе, пандемију, па и чак смрт; корона вирус се плаши њега а не обрнуто; примери тих аспеката су раширени у свим земљама Југоисточне Евопе; уп.:

„,рпп. Još samo da nam Čak Noris obeća obuku lekara protiv Koronavirusa i možemo da odahnemo. ${ }^{20}$

срп. „Чак Норис не носи сат. Он одлучује колико је сати.”21

хрв. , , Koronavirus se zarazio Chuck Norrisom." 22

буг. „Чък Норис хванал Коронавирус, но след това го пуснал.".23

хрв. „Chuck Norris se ukazao gospi u Međugorju."

мак. „Што прави Чак Норис од Ајварот? - Пиперки., ${ }^{25}$

мак. „Чак Норис кога ќе дојде во Македонија, ќе ја исправи Крива Паланка.”26

V. 3. У „чињеницама” о Чаку Норису, његова личност је исто тако важан фактор у историјским као и актуелним политичким догађајима, у економској и друштвеној ситуацији; в. на пример:

срп. „Чак Норис је рођен 6. маја 1945. Немци су се предали 7. маја 1945. Случајност?”27 срп. „Која је разлика између Србије и Чака Нориса? Чак Норис иде напред.”28

хрв. „Chuck Norris se dva puta naljutio u životu ... Historičari to zovu Prvi i Drugi Svjetski rat." ${ }^{29}$

хрв. „,- Ko je otac Chucka Norrisa ? - Aleksandar Veliki!" ${ }^{\text {30 }}$

мак. „Чак Норис еднаш бил во Македонија па затоа не не пуштаат во Европската Унија. Се плашат од нас!"’1

буг. „Дори Бойко Борисов се страхува от Чък Норис.”

\footnotetext{
${ }^{16} \mathrm{https}$ ://www.pcnen.com/portal/2020/03/12/samo-cak-noris-moze-da-zaustavi-koronu/.

${ }^{17} \mathrm{https}: / /$ www.vicevi.rs/vicevi/cak-noris.

${ }^{18} \mathrm{https}$ ://www.vicevi.rs/vicevi/cak-noris.

${ }^{19} \mathrm{https} / / /$ witter.com/RUstipak/status/1237472498742157313.

${ }^{20} \mathrm{https}$ ://twitter.com/BalkanUtopia/status/1237518632550141953.

${ }^{21} \mathrm{https}: / /$ www.vicevi.rs/vicevi/cak-noris.

${ }^{22} \mathrm{http}: / /$ www.mojivicevi.com/chuck-norris/0/.

${ }^{23} \mathrm{https}: / /$ vicove.com/vcat-54.

${ }^{24} \mathrm{http}: / /$ www.mojivicevi.com/chuck norris/.

${ }^{25}$ https://www.facebook.com/Вицеви-за-Чак-Норис-348926355076/.

${ }^{26}$ Vicoteka.mk 19/03/2010 Чак Норис 834.

${ }^{27} \mathrm{https}$ ://www.vicevi.rs/vicevi/cak-noris.

${ }^{28} \mathrm{http}: / /$ www.vicevi.rs/vicevi/cak-noris.

${ }^{29} \mathrm{http}: / /$ www.mojivicevi.com/chuck-norris/.

${ }^{30} \mathrm{http}: / /$ www.mojivicevi.com/chuck-norris/4163-chuck-norris/.

${ }^{31} \mathrm{https}: / / w w w . v i c o t e k a . m k / v i c o v i / c h a k-n o r i s / p a g e / 9 . /$.

32 https://funpic.bg/Вицове-за-Чък-Норис, 218.html.
} 
Да резимирамо, може се рећи да је приповедање на интернету о Чаку Норису широко распрострањено у свим земљама Југоисточне Европе, стога и у Србији. При томе, наравно, међународни наративи највише служе као узор, али његова личност често је повезана са специфичним темама и проблемима сопствене земље и миљеа, у којима је Чак Норис увек победоносни херој.

\section{ЛИТЕРАТУРА}

Господинов 2006: Г. Господинов, Аз живјах сочиализма, 171 лични истории, Пловдив.

Динеков 1976: П. Динеков, Между фолклора и литературата, у: Български фолклор II/1, 3-12.

Кауфман 1982: Н. Кауфман, Градската ни песен от твората половина на XIX век, у: Фолклор и история 6, София, 27-30.

Симонидес 1982: Д. Симонидес, Може ли писана традиција сматрати фолклором? у: Фолклор и история 6, София, 163-170.

Стојкова 1977: С. Стојкова, Фолклорьт и културните промени, у: Фолклор и обитество, София, 31-36.

Bausinger 1980: H. Bausinger, Formen der ,, Volkspoesie”, Berlin.

Bošković-Stulli 1978: M. Bošković-Stulli, Zagrebačka usmena pričanja u prepletanju s novinama i televizijom, y: Narodna umjetnost 15, 11-36.

Čistov 1977: K. Čistov, Aktuelle Probleme der sowjetischen Folkloristik. Jahrbuch für Volkskunde und Kulturgeschichte, N. F. 5, Berlin, 76-74.

Čolović 1994: I. Čolović, Bordell der Krieger. Folklore, Politik und Krieg, Übers. Von K. Wolf-Grießhaber, Osnabrück.

Dégh 1994: L. Dégh, American Folklore and Mass Media, Bloomington/Minneapolis.

Džambo 1993: J. Džambo, Zur Erforschung der Popularliteratur in Jugoslawien. Ansätze, Themen, Probleme, y: Roth, Klaus (Изд.) (1993): Südosteuropäische Popularliteratur im 19. und 20. Jahrhundert, München, 33-54.

Fialkova, Yelenevskaya 2001: L. Fialkova, M. Yelenevskaya, Ghosts in the Cyber World. An Analysis of Folklore Sites on the Internet, In: Fabula 42/1 (2001), 64-89.

Herlin 2008: G. Herlin, Computer im Alltag - Computer als Alltag. Erzählstrategien und biographische Deutungen im Veralltäglichungsprozess von Technik, Dissertation an der Universität Hamburg, Hamburg.

Ludwig 2008: H. Ludwig, Mediale Kommunikation als Vernichter oraler Tradierung? Der Wandel von Oralität und Erzähltradition in Albanien, In: Dahmen, Wolfgang/Himstedt-Vaid, Petra/Ressel, Gerhard (Hgg.): Grenzüberschreitungen. Traditionen und Identitäten in Südosteuropa. FS für Gabriella Schubert. Wiesbaden, 352-365. 
Pistrick 2008: E. Pistrick, Emigration Songs - Interethnic and Multilingual Polyphony in Epirus, y: R. Statelova, A. Rodel, L. Peycheva, I. Vlaeva, V. Dimov, The Human World and Musical Diversity, Sofia, 291-297.

Raskin 1985: V. Raskin, Semantic Mechanisms of Humour, Dordrecht.

Roth 2009: K. Roth, Erzählen im Internet, y: R. W. Brednich (Изд.): Beiträge zur kulturwissenschaftlichen Forschung, Hans-Jörg Uther zum 65. Geburtstag, Berlin/New York, 101-120.

Schneider 1996: I. Schneider, Erzählen im Internet. Aspekte kommunikativer Kultur im Zeitalter des Computers, y: Fabula 37/2, 8-27.

Schubert 1999: G. Schubert, Homo narrans und homo ridens in Südosteuropa. Alltagsbewältigung und Identität in Schwank und Witz, y: Die Welt der Slaven XLIV, 135-154.

Schubert 2011: G. Schubert, Verarbeitungsstrategien der jüngsten Konflikte in Ex-Jugoslawien in Aphorismen, Graffiti, Witzen und Karikaturen, y: G. Ressel, S. Ressel (Изд.): Vom Umgang mit Geschehenem. Kriegsverarbeitung und Friedenssuche in Geschichte und Gegenwart der kroatischen und serbischen Literatur und Kultur, Berlin et al., 189-220 (Trierer Abhandlungen zur Slavistik 10.).

Schubert 2014: G. Schubert, Volksliteraturen des Balkans, insbesondere der Südslaven, y: U. Hinrichs, T. Kahl, P. Himstedt-Vaid (Hrsg.): Handbuch Balkan. Wiesbaden, 541-588.

Sippert 2000: G. Sippert, Chuck Norris und seine Filme, Kaufbeuren, 2000.

\author{
Gabriella Schubert \\ ERZÄHLEN ÜBER CHUCK NORRIS IM INTERNET IN SÜDOSTEUROPA, \\ INSBESONDERE IN SERBIEN
}

Zusammenfassung

Das Erzählen im Internet über den amerikanischen Kampfsportler und Aktionsschauspieler Chuck Norris ist in allen Ländern Südosteuropas, so auch in Serbien, weit verbreitet. Die Aussagen über ihn, in denen seine übernatürliche physische Kraft thematisiert wird, werden ironisch „Fakten” genannt, da sie das Gegenteil zur Realität und zum Wahrscheinlichen darstellen. In ihnen ist Chuck Norris stets der siegreiche Held. Seine Autorität und seine Fähigkeit gehen über physische Kräfte weit hinaus: Er besiegt höhere Mächte, die Pandemie und sogar den Tod: Der Korona-Virus fürchtet sich vor ihm und nicht umgekehrt. Den in Südosteuropa verbreiteten „Fakten” über Chuck Norris dienen zumeist internationale Narrative als Vorbild, doch häufig wird seine Person auch mit spezifischen historischen und aktuellen politischen und sozialen Themen des eigenen Landes und des eigenen Milieu verbunden. 